\title{
Differentiation: The Psychology of Morality
}

God separated the light from the darkness. Genesis 1: 4 NRSV

Differentiation is the act of making differences. In the first Biblical creation story, the very first thing that God does is create differences: light different from dark on day one, sky different from waters on day two, earth different from seas and plants different from trees on day three, sun different from moon on day four, birds different from fish on day five and human beings different from animals on day six.

Differences are important. They are how we know one thing and one person from another. John Duns Scotus stands out as different from his contemporaries in at least three important ways: (1) his conceptualization of the human will as free, which we look at in detail in chapter 5, (2) his conclusion about the Incarnation-as Msgr. Daly underscored for me-that Christ is willed by God regardless of whether human beings sin, which we elaborate in this chapter and (3) his emphasis on the importance of love (emotion)-in addition to intellect (cognition)_for human fulfillment, which we consider throughout the book.

While the differences that God creates are good, the differences that man creates are not always good. Scotus experienced first hand one of our manmade differences: the separation of scientific facts (as set forth by Aristotle) from religious intuitions. Scotus (1266-1308) lived at the time of an intellectual turning point for Western Europeans. Aristotle's Physics, Metaphysics, De Anima and Nicomachean Ethics had just arrived from the Middle East. Aristotle's writings brought with them a new way of explaining reality: from a scientific perspective. According to Aristotle, whose fully developed scientific theory was independent of any religious tradition, human fulfillment is realized in intellectual transcendence. Aristotle encouraged the separation of science and religion.

Scotus differed with Aristotle's philosophical model of intellectual transcendence. He saw love-in addition to intellect-as definitive of human fulfillment and as vital for moral perfection. Scotus built "a view of the world that included the voice of the non-believer (Aristotle), and showed how the deepest aspirations of human nature are fulfilled ..." (Ingham, 2003, 29). They are fulfilled with love. To quote Scotus's Ordinatio III, suppl., dist. 27, "Not only does God's infinite goodness... draw us to love such, but because this 'Goodness' 
loves me, sharing itself with me, therefore I elicit an act of love towards it. ... God is worthy of love not only for what he is in himself, but also because he shares himself and is our good as well; hence he deserves to be loved in return, according to that text from John: 'Let us love God because he has first loved us'" (Wolter, 1986/1997, 278).

"The Franciscan [Scotus] consistently defends a position wherein the fullest perfection of the human person as rational involves loving in the way God loves, rather than knowing in the way God knows" (Ingham \& Dreyer, 2004, 8). In the words of Professor of Philosophy Mary Beth Ingham, "Love completes our actions in the creation of relationships with others and, especially, with God" (Ingham, 1996, xv). The major foundation for moral living for Scotus is not obligation or law alone, but also love and relationship.

\section{RELATIONSHIP}

As the Biblical creation stories tell us, God created humankind in his image. God has given us the capacity to be cocreators with Him in the process of creation. We human beings enter life with bodies capable of cocreating a moral world within loving relationships. What does Scotus tell us about human relationships and about the contribution of relationships to human morality?

Scotus and relationship. We know very little about Scotus's living relationships because the details of his life are quite obscure. He seems to have been born in Duns, Scotland around the year 1266. Leaving home in early adolescence, he entered the Franciscan Order of Friars Minor. Most likely he began his formal studies of theology in 1288. On March 17, 1291 he was ordained to the priesthood at Saint Andrew's Priory, Northampton, England. He lectured at Oxford until he was appointed to Paris in 1302. While in Paris, political events-King Philip's effort to depose Pope Boniface VIII, which Scotus opposed-interrupted his intellectual studies and teaching. Scotus and other Franciscans who opposed King Phillip IV were exiled (1303-1304). After Benedict XI succeeded Boniface as Pope, he lifted the ban placed on the University of Paris and King Philip IV allowed Scotus's return to Paris. On November 18, 1304 Scotus was pronounced Franciscan Regent Master of Theology, an event comparable to finishing his doctorate after a decade or more of formal study. He died an untimely death three years later in 1308 at the age of forty-two and is buried in the Franciscan church not far from the Cologne cathedral (Ingham, 2003, 13-17; Williams, 2003).

Although we know little about Scotus's relationships in life, we know a great deal about his emphasis on relationships with regard to moral living. His conceptualization of human morality can be understood-as Scotus scholar Mary Beth Ingham does-by comparing it to a wind chime (Ingham, 1996, 145147). The wind chime consists of individual pieces that must hang in appropriate 
relationship to each other for the chime to appear visually beautiful and to sound musically harmonious. According to Scotus human morality is like this. People are individuals who must be in appropriate relationship within their community to flourish morally.

The chime must also be balanced. This does not mean that all pieces must be the same size. Two small pieces may balance one large piece. But, the entire chime must be balanced. In Scotus's thinking balance symbolizes the end of our moral journey, which is communion, not autonomy.

At the center of every wind chime is a disk. Scotus's central element of morality is the freedom of the will, which we explore in chapter 5. It is weighted by desire that focuses in two directions: desire that focuses inward and desire that focuses outward. But, it is free enough to be moved by the circumstances in which it lives. Just as the disk moves to touch the chimes, each person-using free will-functions in context touching other people.

The chimes surrounding the disc represent not only other people, but also their moral virtues - their practical habits resulting in morally good acts that are set in time, place, manner and circumstances. According to emeritus professor of philosophy at Loyola University in Chicago, Francis ]. Catania, the "root meaning [of virtue] is 'power'-power over ourselves, within greater or lesser limits-to become what in God's eyes we are" (Catania, 2010, 64).

According to Scotus, each person using free will can function properly only with other people and their virtues. Together they function best when they function in harmony. "Together, the human goods of balance and harmony constitute that inner peace which gives rise to joy within the heart of the formed moral agent" (Ingham, 1996, 147). The moral agent-like the wind chimeresponds to what circumstances demand.

Relationship, thus, is central to Scotus's vision of morality. What do psychiatry and neuroscience tell us about relationship?

Behavioral science and relationship. Behavioral science also places relationships at the center of human moral development. Because Attachment Theory has been the dominant approach to understanding the early social and emotional development of human beings during the past quarter-century of research, I choose to use it-rather than other contemporary psychological theories-to show how behavioral science's view of relationship connects with Scotus's view of relationship.

Much began with John Bowlby, a British medical doctor and psychoanalyst, who defined and elaborated the concept of attachment. He proposed that human beings begin life with an inborn capacity that promotes attachment to their mother (Bowlby, 1969). In observing his own children, Bowlby noted what mothers have long known: attachment seeking is instinctive social behavior that maintains a child's closeness to its caregiver upon whom it depends for biological survival. Bowlby supplemented his observations of his own children 
with scientific studies of mother-child relationships. He described scientifically how these early relationships become the ways that people bond to one another throughout life.

Mary Ainsworth, Bowlby's associate, expanded Bowlby's view of attachment seeking by recognizing that children need not only closeness to caregivers but also emotional access in order to form attachment bonds of emotional communication. For scientifically investigating emotional access, Ainsworth invented a procedure called the Strange Situation Test (Ainsworth et al., 1978). In this laboratory procedure both child (twelve to twenty months of age-at the height of separation anxiety) and caregiver play in a room with a one-way window. A one-way window allows researchers to view and to videotape the child-caregiver interactions without child and caregiver seeing them.

The room is supplied with toys that child and caregiver are free to play with. After child and caregiver interact for a few minutes, a friendly stranger (an experimenter) joins them. The caregiver then leaves the room, returns after three minutes and resumes playing with the child and the experimenter. Then, both caregiver and experimenter leave. After another three minutes, the caregiver returns, which ends the experiment. Later, researchers view the taped situation and code the caregiver-child interactions with regard to separation and reunion behaviors. They classify the child according to one of three attachment patterns described by Ainsworth: secure attachment to his or her caregiver, insecureavoidant attachment or insecure-resistant attachment. A student of Ainsworth, Mary Main, has added a fourth category: disorganized-disoriented attachment.

The secure attachment reflects a mother-child relationship that promotes wellbeing and serves as a source of resilience in stress. Mother's style of relating is one of being available to and effective with her child. The child's style of relating shows distress at Mother's departure, but comfort with Mother's return.

An insecure-avoidant attachment reflects a mother-child relationship that is impoverished. Mother's style of relating is one of being distant and rejecting. The child exhibits no overt distress when Mother leaves and on her return, does not seek to be near her.

An insecure-resistant attachment reflects a mother-child relationship where Mother is inconsistently available. The child exhibits distress even prior to Mother's leaving and is difficult to sooth and unable to play when Mother returns.

A disorganized-disoriented attachment differs from the other three in that the other three attachments are organized. A disorganized-disoriented attachment

1 I use "Mother" in describing Table 2.1 because early studies used mother-child interactions. However, "Father" or other "caregiver" and child relationships can be characterized as described in Table 2.1. 
Table 2.1

Attachment Patterns

Summary of Findings from Attachment Research

\begin{tabular}{|l|l|l|}
\hline Parenting Behavior & $\begin{array}{l}\text { Child's Strange Situation } \\
\text { Test }\end{array}$ & $\begin{array}{l}\text { Adult Attachment } \\
\text { Interview }\end{array}$ \\
\hline $\begin{array}{l}\text { Autonomous } \\
\text { perceptive, and effective }\end{array}$ & $\begin{array}{l}\text { Secure Attachment } \\
\text { Child shows distress } \\
\text { when mother leaves but } \\
\text { is comforted by reunion, } \\
\text { returns to play }\end{array}$ & $\begin{array}{l}\text { Detailed memory, balanced } \\
\text { perspective, coherent } \\
\text { autobiographical narrative }\end{array}$ \\
\hline $\begin{array}{l}\text { Dismissing } \\
\text { Distant and rejecting }\end{array}$ & $\begin{array}{l}\text { Insecure-Avoidant } \\
\text { Attachment } \\
\text { Child exhibits no overt } \\
\text { distress at mother's leaving } \\
\text { and on her returning } \\
\text { does not seek to be near } \\
\text { her, appears to play } \\
\text { uninterrupted }\end{array}$ & $\begin{array}{l}\text { is emotionally bland, } \\
\text { dismisses the importance of } \\
\text { interpersonal relationships }\end{array}$ \\
\hline $\begin{array}{l}\text { Enmeshed-Ambivalent } \\
\text { Inconsistent availability }\end{array}$ & $\begin{array}{l}\text { Insecure-Resistant } \\
\text { Attachment } \\
\text { Child exhibits distress even } \\
\text { prior to mother's leaving } \\
\text { and on her returning is } \\
\text { difficult to sooth, doesn't } \\
\text { play }\end{array}$ & $\begin{array}{l}\text { fays } \\
\text { negative emotions, } \\
\text { incoherent autobiographical } \\
\text { narrative }\end{array}$ \\
\hline $\begin{array}{l}\text { Disorganized } \\
\text { Disorienting or } \\
\text { frightening }\end{array}$ & $\begin{array}{l}\text { Disorganized-Disoriented } \\
\text { Attachment } \\
\text { Child is frightened by } \\
\text { mother's leaving but on } \\
\text { her return, he exhibits } \\
\text { contradictory attachment } \\
\text { behaviors, e.g. when he } \\
\text { rises at mother's return, fear } \\
\text { overwhelms him and he falls } \\
\text { prone on the floor }\end{array}$ & $\begin{array}{l}\text { Disorganized and confusing } \\
\text { autobiographical narrative }\end{array}$ \\
\hline
\end{tabular}

We see several things:

1. The adults' ways of thinking about childhood influence their way of relating to the infant.

2. The child's relatedness to mother shapes the way the child relates to others.

3. Personal relationships shape thinking.

Sources: Mary D.S. Ainsworth, M.C. Blehar, E. Waters and S. Wall, Patterns of Attachment: A Psychological Study of the Strange Situation (Hillsdale, NJ: Lawrence Erlbaum, 1978); John Bowlby, Attachment (New York: Basic Books, 1969); Erik Hesse, "The Adult Attachment Interview: Historical and Current Perspectives," In Handbook of Attachment: Theory, Research, and Clinical Applications, ed. J. Cassidy and P. Shaver (New York: Guilford, 1999), 395-433; Erik Hesse and Mary Main, "Second-Generation Effects of Unresolved Trauma as Observed in Non-Maltreating Parents: Dissociated, Frightened and Threatening Parental Behavior," Psychoanalytic Inquiry vol. 19 (1999), 481-540; Erik Hesse and Mary Main, "Disorganized Infant, Child, and Adult Attachment: Collapse in Behavioral and Attentional Strategies," Journal of the American Psychoanalytic Association vol. 48, no. 4 (2000), 1097-1127. 
is not organized and reflects a mother-child relationship in which the Mother is a source of terror or alarm. The child is frightened by Mother's departure and shows contradictory behaviors when Mother returns. For example, the child may rise as if to go to Mother but instead falls prone to the floor.

The original attachment patterns seem to be very stable. Some children studied in the Strange Situation Test have been followed up to nineteen years of age. Their original attachment patterns predict their subsequent behavior patterns especially their patterns of relating with parents, teachers and peers.

Eventually interest arose about caregivers' attachment patterns. To study caregivers, Mary Main, together with Eric Hesse, developed the Adult Attachment Interview. This interview elicits a story of the adults' childhood memories of separations and losses, memories of illnesses, memories of feelings such as feeling loved or unloved and it measures whether the adult makes sense of how those experiences have affected them (Hesse, 1999). Main and Hesse rate various aspects of the remembered story to determine the adults' attachment patterns. Here, too, attachment patterns show a continuity of relationship bonds. The adults' characteristic ways of remembering their own parent-child relationships reflect how the adults bonded with their parents in the past and predict how the adults will bond with their own children in the present or in the future (see Tab.2.1). At least this continuity of relationship bonds applies to those who live in contemporary Western culture (Belsky, 2005; Hesse \& Main, 1999; Hesse \& Main, 2000).

In summary, it seems that the way we human beings develop emotionally and socially is organized in our bodies through relationships (Schore, 1994; Schore, 1999; Schore, 2000a; Schore, 2000b; Siegel, 1999; Uddin et al., 2005). Those participating in the relationships cocreate attachment bonds of emotional communication. Attachment bonds represent the ways our human nervous system regulates our emotions both between us and others and also within each of us. "Attachment, then, is a memory template for human-to-human bonds. This template serves as our primary 'world view' on human relationships" (Perry \& Szalavitz, 2006, 85).

To the extent that attachment bonds exist in our nervous system as memories, we can say that they are incarnate.

\section{INCARNATION}

Incarnation according to Webster's Seventh New Collegiate Dictionary means embodiment, the putting of something in the form of a body. What does incarnation mean for Scotus?

Scotus and incarnation. For Scotus the Incarnation refers to the embodiment of God in Jesus the Christ. His understanding of why God created Jesus Christ differentiates him from those who came before him. Before Scotus, the common belief was that God created Christ because of man's sin (Mulholland, 2008). Scotus, however, given the scriptural teaching that God is love, concludes that God created 
Christ as his summum opus Dei. Christ is God's masterpiece of all created human beings and God's love is reason enough to create his masterpiece. God did not need man's sin as a reason to create Christ.

Remember the wind chime-the piece of art that is the image of Scotus's conceptualization of human morality? Scotus views God as the divine artist whose works of beauty exhibit unity, truth and goodness. The Incarnation exhibits all three attributes.

First, the Incarnation exhibits unity. The Incarnation is God's creation of human and divine union in one person Jesus Christ. This unity shows us God's intention to share divine life with every one of us human beings. Our ultimate goal in life is union with God. Erasure of boundaries is the purpose of the Incarnation-the union of divinity with humanity. In Scotus's view, "The purpose of the Incarnation is not to remove something bad [original sin]; it is to facilitate a higher perfection [union with God]" (Ingham, 2003, 76-77). Human nature needs the Incarnation to show us the way to union with God.

Second, the Incarnation exhibits truth. According to Scotus, even if human nature were sinless, we would need Jesus Christ to show us a higher perfection about relationship and unconditional commitment. In Jesus Christ we see the truth that God can initiate and sustain relational presence. In Jesus Christ we see our true model for human actions.

Third, the Incarnation exhibits goodness. The Incarnation is the fullest manifestation of God's goodness-God's love for human beings. Scotus believed that the "world was created so that there would be a world in which to become incarnate" (Ingham, 2003, 75). As we read in the Biblical creation story, God established a distinct relationship to human beings when He created them. Later He confirmed this relationship with Abraham and the people of Israel. Then He fulfilled this relationship in the person of Jesus Christ in the Incarnation.

The Incarnation reveals God's loving desire to be with us. Human nature, according to Scotus, was created with the natural capacity to love God. We all have it. God created us with this natural capacity so that we can receive the Incarnation in us and with us. I am reminded again of what my friend, Msgr. Daly, told me years ago: the Son of God came to earth among us innocent creatures to fill us with grace, to receive our worship, to enjoy our company and to show us the way to eternal life.

Scotus views the Incarnation as a manifestation of God's goodness and God's wish to dwell within us. How, then, does behavioral science view incarnation?

Behavioral science and incarnation. For behavioral science, incarnation is the way relationships organize our human nervous system that, in turn, coordinates our moral body. Behavioral science, however, does not use the world "incarnation"; instead, neuroscience speaks of "embodiment."

As Bowlby and his followers have established scientifically, we humans are born with a capacity to connect and relate to others. Biologist Edward O. Wilson agrees: Human beings are ruled by "an urge" (Wilson, 2012, 244) to seek a group. 
This urge to seek a group, this capacity to connect with others is part of our body like our genes are part of us. Like our genes, this capacity remains a potential until it is turned on. It is turned on by relationships-by another meeting us. When another meets us in harmony, our capacity to connect develops in the direction of coming into the fullness of our being and experiencing the depth of our longing for goodness. (In chapter 6 we learn what happens when we are met in disharmony.)

You may ask, "What does meeting us in harmony mean?"

The experience might be as simple as a baby crying when hungry or soiled and a mother responding by feeding or changing a diaper, or as complex as an adult reading a facial expression of delight when a baby smiles and responding with a joyous smile. The bodies of both are engaging and changing in a process such as this: When the infant's face expresses his feelings, Mother's body is activated as if she were feeling the same emotions. Her embodied experience now gets expressed on her face and is reflected back to the infant. Seeing this emotional confirmation of his feelings, the infant knows in his deepest level that he is known within his mother's deepest level.

Through harmonious interactions the infant also learns how to regulate within itself the emotions that Mother is coregulating between them within their relationship. In a secure attachment relationship, Mother is both downregulating the infant's states of fear and distress and also up-regulating states of joy and excitement in play experiences.

Mother is also creating an interpersonal relationship in which the infant feels that it is valued and valuable to Mother. Mother also feels valuable and valued. The two are cocreating a secure attachment pattern that reflects trust that key people will be available and supportive in times of need. In this cocreating process, human beings come to know each other directly by seeing and experiencing the motor actions and emotional feelings of each other. Neuroscientist Vittorio Gallese (2005) calls this direct influence: embodied simulation. Embodied simulation is the sense of embodiment that I use when I claim that psychiatry includes a view of a "moral body."

Embodied simulation is the way we understand another's actions and emotions directly without thinking about them. It involves recognizing, anticipating and interpreting the actions and emotions of another. We do this when we automatically match the goal-directed motor actions of another with the motor activation of our own brain and body-states. We also do this when we automatically match the emotions of another with the visuomotor and sensorimotor activation of our own brain and body-states. Put simply, we understand another when our body automatically places us in a body-state like the body-state of the other. Through embodied simulation, others become us. Our bodies are created to do this, as we will see in ensuing chapters.

From their earliest non-verbal visual, auditory and tactile communications to their infant, caregivers communicate the love or fear that becomes the foundation 
for the infant's attachment patterns, brain integration, emotional regulation and moral development. In psychologist Allan Schore's words, "The caregiver influences the trajectory of the child's developing moral capacities by shaping the neurobiological structural system that mediates such functioning" (Schore, 1994, 354). Caregivers shape their children's moral bodies. When this is done lovingly, caregivers continue the miracle of creation and bring love into the universe.

Caregivers also convey to their children the virtues that their community values.

\section{VIRTUES}

Aristotle's Nichomachean Ethics describes virtues as traits that are found on a continuum between a deficiency on one end and an excess on the other end. For example, generosity is a virtue that exists between miserliness and being profligate. In general, virtues have historically been considered to be distinct qualities or traits of mankind. Today, we commonly think of virtues as conformity to standards of what is right that results in moral excellence. "[T]heir practice represents the sort of person we wish to become" (Catania, 2010, 66). How does Scotus address virtue?

Scotus and virtues. As the wind chime image of Scotus's conceptualization of morality suggests, the chimes represent both people with whom we interrelate and also their moral virtues. Moral virtues are acquired dispositions or practical habits "that incline us to choose rightly" (Wolter, 1986/1997, 78). "In other words, moral virtue refers to any natural disposition or habit that is within the power of the will in the activity of rational deliberation, choice and execution" (Ingham \& Dreyer, 2004, 195). In summary, Scotus understands virtues to be natural dispositions toward right action. They do not ground or define moral action, but they are significant to moral action.

They are secondary for moral choice-secondary to our human free will (symbolized by the disc at the center of the wind chime) that enables human beings to choose our moral actions. Moral virtues are an aid to our moral choices in that they add the timing, the place, the manner and the circumstances that influence our motivation to choose correctly. "Virtue for Scotus is more to be identified with motivation than with performance: moral excellence is the perfection of motivation" (Ingham, 1996, 93).

For Scotus, then, there are two components to moral living: a free component and a natural component (Ingham, 1996, 86). The free component has to do with our will, as we explore more completely in chapter 5 . The natural component involves our learned inclinations, our virtues that draw our will toward what is good. Professor of Philosophy Bonnie Kent divides Scotus's approach to the role of virtue in moral action into two questions: "(1) What makes an action a moral action? and (2) What makes an action morally good?" (Kent, 2003, 355).

What makes an action a moral action? For an action to be a moral action it must have two characteristics. First, the action must not be automatic like a 
reflex. Rather it must be within the person's control, for which he can be held responsible. Second, the action must be a choice of free will. In Kent's words, "[M]oral responsibility requires that an agent be capable not only of different acts but also of significantly different motivations for acting" (Kent, 2003, 356).

What makes an action morally good? Virtue is neither a sufficient nor a necessary condition for moral goodness. Because virtue is a natural component to moral living, if the cause of an act is totally or principally a virtue, the act will be natural, not moral and not morally good. "An act is morally good because it conforms to all that the agent's [person's] right reason dictates: for example, the appropriate time and place, and above all, the appropriate end" (Kent, 2003, 359). Kent says, "I act virtuously only when I choose [free will] to act in accordance with my virtuous dispositions [values]" (Kent, 2003, 361).

In moral development the free and natural elements work in close relationship such that the morally mature person lives with integrity of character. To the extent that virtues influence free and rational choice, they contribute to moral character. "The best human behavior therefore combines the free choice of the will and the natural causality of dispositions" (Kent, 2003, 363). Scotus's perspective focuses on the person. "The person is the moral subject: both as end and as source for moral activity. Moral development involves development of the person, one who is able to respond rationally and freely, morally and creatively, to the demand of a given situation" (Ingham \& Dreyer, 2004, 200).

We see in Scotus's understanding of virtues that he intuitively accessed truths that science is currently rediscovering. What is behavioral science rediscovering?

Behavioral science and virtues. Jonathan Haidt, one of the top moral psychologists, with his colleague, Craig Joseph, have studied moral systems in great detail (Haidt \& Joseph, 2007; Haidt \& Bjorklund, 2008). I find that their perspective parallels Scotus's because they take a social intuitionist approach to moral psychology. Thus, they take into consideration our automatic responses to social triggers.

Haidt and his colleagues find that they can explain most moral concerns in the world cultures with five universal moral modules. ${ }^{2}$ Their five modules (see Table $2.2^{3}$ ) are reciprocity (a sense of fairness), suffering (help versus harm of others), hierarchy (respect for elders), coalitions (group loyalty) and purity (praising cleanliness).

2 Modules are mental propensities that enable fast and automatic responses to specific environmental triggers.

3 Table 2.2 is constructed from Michael Gazzaniga's understanding of Haidt and Joseph's work as noted in the sources of Table 2.2. Haidt has subsequently added a sixth module and he now calls them foundations. His six foundations are: Care/harm, Liberty/oppression, Fairness/cheating, Loyalty/betrayal, Authority/subversion, and Sanctity/degradation. See Jonathan Haidt, The Righteous Mind: Why Good People are Divided by Politics and Religion (New York: Pantheon Books, 2012). 
Table 2.2

Five Universal Moral Modules.
1. Reciprocity Module
Environmental Trigger: social exchange
Moral Emotions Elicited: sympathy, contempt, anger, guilt, shame, gratitude
Moral Intuition: reciprocity
Ethic: autonomy
Virtues: sense of fairness, justice, trustworthiness, patience
Vices: dishonesty

\section{Suffering Module}

Environmental Trigger: survival

Moral Emotions Elicited: sympathy, compassion, empathy

Moral Intuition: mimicry

Ethic: autonomy

Virtues: compassion, kindness

Vices: righteous anger, cruelty

\section{Hierarchy Module}

Environmental Trigger: status

Moral Emotions Elicited: guilt, shame, respect, awe, resentment

Moral Intuition: social acceptability

Ethic: community

Virtues: respect, obedience, deference

Vices: disobedience, uppitiness

\section{Coalitions Module}

Environmental Trigger: in-group/out-group threat

Moral Emotions Elicited: compassion or contempt for other groups, anger, guilt, shame,

embarrassment, gratitude

Moral Intuition: mimicry

Ethic: community

Virtues: trust, cooperation, self-sacrifice, loyalty, patriotism, heroism

Vices: treason, cowardice

\section{Purity Module}

Environmental Trigger: defense against disease

Moral Emotions Elicited: disgust

Moral Intuition: dirty, bad, avoid; clean, good, approach

Ethic: divinity

Virtues: cleanliness, chastity, temperance

Vices: lust, intemperance

Sources: Michael S. Gazzaniga, Human: The Science Behind What Makes Us Unique(New York: HarperCollins, 2008); Jonathan Haidt and Craig Joseph, "The Moral Mind: How Five Sets of Innate Intuitions Guide the Development of Many Culture-Specific Virtues and Perhaps Even Modules," In The Innate Mind, Vol. 3: Foundations and the Future, eds. Peter Carruthers, Stephen Laurence, and Stephen Stich (New York: Oxford University Press, 2007), 367-391; Jonathan Haidt and Fredrik Bjorklund, "Social Intuitionists Answer Six Questions about Moral Psychology," In Moral Psychology: The Cognitive Science of Morality: Intuition and Diversity, ed. Walter Sinnott-Armstrong (Cambridge, MA: The MIT Press, 2008), 181-217.

Each module is characterized by an environmental trigger and what the trigger elicits: moral emotions, a moral intuition, an ethic, virtues and vices. For example, the reciprocity module's environmental trigger is social exchange. Social exchange elicits the moral emotions of sympathy, contempt, anger, guilt, shame and gratitude. Social exchange elicits the moral intuition of reciprocity; 
the ethic of autonomy; the virtues of sense of fairness, justice, trustworthiness and patience; and the vice of dishonesty.

According to Haidt and Joseph, morality is grounded in these five innate modules. Innate means that these modules are organized, to some extent, in advance of experience. Put another way, human beings are born with a preparedness to acquire these kinds of moral knowledge. Our bodies are prewired for morality. While a child requires guidance to configure these five moral propensities properly, each of the five modules matures at a specific point in human psychobiospiritual development (suffering at two years old; reciprocity after three years old; purity after seven years old). During moral development persons acquire attributes associated with each module that help them navigate their social world.

One of the attributes associated with each module is called "virtues" (see Tab.2.2). Haidt and his colleagues seem to mean what Scotus means by "virtues." Virtues are complex rational, emotional and social skills that have innate potentials. These innate potentials, however, require general rules and practice to become good habits.

Virtues are cultural ideals specific to each society. For example, within the reciprocity module, one culture might value fairness while another culture might promote the virtue of patience. In all cultures, however, moral development is a process in which the five innate moral modules meet "up with a particular set of socially constructed virtues" (Haidt \& Bjorklund, 2008, 208-209)_producing individuals suited to thrive in their culture.

Human beings are a supreme species with regard to culture. Culture, as I use it here, means massive collections of skills and knowledge. We transmit culture from person to person through imitation of action or language. We can do this because of the way our bodies are created.

Let us focus first on our body anatomy. 